\title{
Survey on the Education System and National Licensing Examination for Fostering Competent Medical Technologists
}

Hong Sung Kim ${ }^{1}$, Pil Seung Kwon ${ }^{2}$, Ji-Hyuk Kang ${ }^{3}$, Man-Gil Yang ${ }^{4}$, Jong O Park ${ }^{5}$, Dae-Joong Kim ${ }^{6}$, Won Shik Kim ${ }^{7}$, Sei Ick Joo ${ }^{8}$, Eun-Joong Kim, Sun Kyung Lee ${ }^{10}$, Sang Hee Lee ${ }^{11}$, Seung-Joo Jekal ${ }^{2}$

${ }^{1}$ Department of Medical Laboratory Science, Korea Nazarene University, Cheonan, Korea

${ }^{2}$ Department of Clinical Laboratory Science, Wonkwang Health Science University, lksan, Korea

${ }^{3}$ Department of Biomedical Laboratory Science, DaeJeon University, Daejeon, Korea

${ }^{4}$ Department of Research \& Experiments, Biomedical Research Institute, Seoul National University Hospital, Seoul, Korea

${ }^{5}$ Department of Nuclear Medicine, Samsung Medical Center, Seoul, Korea

${ }^{6}$ Department of Laboratory Medicine, Bundang Jesaeng Hospital, Seongnam, Korea

${ }^{7}$ Department of Clinical Laboratory Science, Daejeon Health Institute of Technology, Daejeon, Korea

${ }^{8}$ Department of Laboratory Medicine, Seoul National University Hospital, Seoul, Korea

Department of Clinical Laboratory Science, Chungbuk Health and Science University, Cheongju, Korea

${ }^{10}$ Department of Clinical Laboratory Science, Dongkang College, Gwangju, Korea

${ }^{11}$ Department of Clinical Laboratory, Asan Medical Center, Seoul, Korea

\section{우수한 임상병리사 양성을 위한 교육제도 및 국가면허시험제도에 대한 설문조사 분석}

김홍성 ${ }^{1}$, 권필승 $^{2}$, 강지혁 $^{3}$, 양만길 ${ }^{4}$, 박종오 $^{5}$, 김대중 $^{6}$, 김원식 $^{7}$, 주세익 ${ }^{8}$, 김은중 $^{9}$, 이선경 $^{10}$, 이상희 $^{11}$, 제갈승주 $^{2}$

${ }^{1}$ 나사렛대학교 임상병리학과, ${ }^{2}$ 원광보건대학교 임상병리과, ${ }^{3}$ 대전대학교 임상병리학과, ${ }^{4}$ 서울대임상의학연구소, ${ }^{5}$ 삼성서울병원 핵의학과, ${ }^{6}$ 분당제생병원 진단검사의학과, ${ }^{7}$ 대전보건대학교 임상병리과, ${ }^{8}$ 서울대학병원 진단검사의학과, ${ }^{9}$ 충북보건과학대학교 임상병리과, ${ }^{10}$ 동강대학교 임상병리과, ${ }^{10}$ 서울아산병원 진단검사의학과

\begin{abstract}
This study aimed at characterizing policy directions to foster competent medical technologists by analyzing the opinions of professors and medical technologists regarding university education and national licensing systems. An online survey questionnaire was distributed to 255 professors and 4,000 medical technologists in August of 2016. Fifty-nine professors (23\%) and 1,099 medical technologists (27.7\%) responded to the survey. The results were evaluated using descriptive statistics and comparative analysis. Professors and medical technologists agreed that there needs to be an improvement and standardization in both education at universities and practical training at hospitals. Moreover, both groups also thought that it was necessary to reform practical examinations and make improvements in the current licensing system. According to the survey results, professors and medical technologists thought that, the improvement of the quality of university education and hospital practical training should be essential, and the reform of existing national licensing examination should be necessary.
\end{abstract}

Key words: Education system, National licensing examination, Survey

This is an Open Access article distributed under the terms of the Creative Commons Attribution Non-Commercial License (http://creativecommons.org/licenses/by-nc/4.0) which permits unrestricted non-commercial use, distribution, and reproduction in any medium, provided the original work is properly cited.

Copyright (C) 2017 The Korean Society for Clinical Laboratory Science. All rights reserved.
Corresponding author: Seung-Joo Jekal Department of Clinical Laboratory Science, Wonkwang Health Science University, 460 Iksan-daero, Iksan 24252, Korea Tel: 82-63-840-1215 Fax: 82-63-840-1219 E-mail: sjjei@wu.ac.kr

Received: April 27, 2017 Revised $1^{\text {st. }}$ : May 8, 2017 Revised $2^{\text {nd }}$ : May 22, 2017 Accepted: May 23, 2017 


\section{INTRODUCTION}

The current Korean medical technologist education and training process consists of university education, practical training at hospitals, a national license examination, retraining after obtaining the license, and management. There are many studies about university education [1,2] and practical training at hospital [3,4]. However, the parts of the process as a whole do not interconnected or managed in a systematic manner. Each institution including university, hospital, Korea Health Personnel Licensing Examination Institute (KHPLEI) manage the individual parts of the process independently. As a result, the components of the entire process are not fully communicating or cooperating with one another, and it is hard to say that an integrated system for fostering expert medical technologists is managed successfully. In this study, therefore, a survey has conducted by professors responsible for university education and medical technologists currently working in medical institutions with the objective of contributing to strengthening of the capacity of medical technologists to follow the changes in the public health and medical environments. This study examined respondents' opinions of the university education system, qualification requirements for university professors, criteria for the educational environment, development of a standardized curriculum, a framework for university experiments and training courses, hospital practical training, the foundation of Korean Accreditation of Board of Medical Technology, and the current national licensing examination system. It examined options for developing a new direction and suggested policy directions required for an integrated system for establishing the most effective measures for producing competent medical technologists.

\section{MATERIALS AND METHODS}

\section{Study design}

This study is descriptive analysis of survey data. Survey questionnaire formulated based on literature analysis and validity test.

\section{Subjects and methods}

The content of question was obtained using data from an analysis of the literature as well as the focus group interview that comprised 7 professors and 5 medical technologists. We prepared the questionnaires according to the results, and received consultation from the Korea Association of Medical Technologists (KAMT) and the Korean Association of Biomedical Laboratory Science Professors (KABLSP) for confirming content validity. To identify opinions of professors and medical technologists, a questionnaire-based survey was conducted online by respondent's consent. The questionnaire was distributed to professors at departments of medical technology and medical technologists at hospitals across the country on August 17, 2016, and was retrieved on August 22, 2016. Fifty-nine professors (23\%) responded to the survey out of a total 255 , and 1,099 medical technologists $(27.7 \%)$ out of 4000. In keeping with the study's objective, the questionnaire consisted of a general section, an education system section, and a national licensing examination system section. The questions consisted of questions with 5-point Likert scales from "strongly disagree" (1 point) to "strongly agree" (5 points), and selection questions.

\section{Statistical analysis}

The data analyzed using SPSS. Their validity tested by percentages, averages, and standard deviations. The significance of the results between the two groups measured through a Student's t-test.

\section{RESULTS}

\section{The general characteristics of subjects}

The general information of professors and medical technologists has shown in Table 1.

\section{Education system}

1) Qualification requirements for professors

Sixty-seven percent and 68\% of the professors agreed 
Table 1. The general information of professors and medical technologists

\begin{tabular}{|c|c|c|c|}
\hline \multicolumn{2}{|c|}{ Classification } & Percent (\%) & Note \\
\hline \multicolumn{4}{|l|}{ Professors (N=59) } \\
\hline \multirow[t]{3}{*}{ Sex } & Male & 64.41 & male $>$ female \\
\hline & Female & 33.90 & \\
\hline & Other & 1.69 & \\
\hline \multirow[t]{6}{*}{ Age } & Twenties & 0.00 & forties $>$ fifties $>$ sixties $>$ thirties \\
\hline & Thirties & 8.47 & \\
\hline & Forties & 45.76 & \\
\hline & Fifties & 33.90 & \\
\hline & Sixties & 10.17 & \\
\hline & Other & 1.69 & \\
\hline \multirow[t]{3}{*}{ Academic degree } & Master & 3.39 & doctor $>$ master \\
\hline & Doctor & 91.53 & \\
\hline & Other & 5.08 & \\
\hline \multirow[t]{6}{*}{ Career } & $1 \sim 5$ year & 23.73 & below 10 year: $60 \%$, \\
\hline & $6 \sim 10$ year & 37.29 & above 11 year: $36 \%$ \\
\hline & $11 \sim 15$ year & 3.39 & \\
\hline & $16 \sim 20$ year & 6.78 & \\
\hline & Above 20 year & 27.12 & \\
\hline & Other & 1.69 & \\
\hline \multirow{5}{*}{ Job grade } & Lecture-charged & 1.69 & assistant professor $>$ \\
\hline & Assistant professor & 45.76 & associated professor $>$ professor \\
\hline & Associated professor & 27.12 & \\
\hline & Professor & 23.73 & \\
\hline & Other & 1.69 & \\
\hline \multirow[t]{7}{*}{ Work region } & Seoul & 0.00 & Chungcheong $>$ Gyeongsang $>$ \\
\hline & Gyeonggi & 15.25 & Gyeonggi = Jeolla > Gangwon, Jeju \\
\hline & Chungcheong & 37.29 & \\
\hline & Gyeongsang & 23.73 & \\
\hline & Jeolla & 15.25 & \\
\hline & Gangwon, Jeju & 6.78 & \\
\hline & Other & 1.69 & \\
\hline \multicolumn{4}{|c|}{ Medical technologists $(\mathrm{N}=1,099)$} \\
\hline \multirow[t]{3}{*}{ Sex } & Male & 33.76 & female $>$ male \\
\hline & Female & 64.60 & \\
\hline & Other & 1.64 & \\
\hline \multirow[t]{6}{*}{ Age } & Twenties & 29.57 & thirties $>$ twenties $>$ forties $>$ fifties \\
\hline & Thirties & 31.76 & \\
\hline & Forties & 24.75 & \\
\hline & Fifties & 11.28 & \\
\hline & Sixties & 1.09 & \\
\hline & Other & 1.55 & \\
\hline \multirow[t]{5}{*}{ Academic degree } & Associate & 39.22 & bachelor $>$ associate $>$ master $>$ doctor \\
\hline & Bachelor & 41.95 & \\
\hline & Master & 10.19 & \\
\hline & Doctor & 6.28 & \\
\hline & Other & 2.37 & \\
\hline \multirow[t]{4}{*}{ Job title } & Laboratory technologists & 49.77 & laboratory technologist > \\
\hline & Laboratory supervisor & 24.84 & laboratory supervisor > \\
\hline & Laboratorymanagers & 21.93 & laboratory managers \\
\hline & Other & 3.46 & \\
\hline Career & $1 \sim 5$ year & 40.13 & below 10 year: $61 \%$, \\
\hline & $6 \sim 10$ year & 21.38 & above 11 year: $34 \%$ \\
\hline & $11 \sim 15$ year & 11.46 & \\
\hline & 16 20 year & 8.83 & \\
\hline & Above 20 year & 15.56 & \\
\hline & Other & 2.64 & \\
\hline Hospital size & Above 500 persons & 33.94 & above 500 persons $>$ below 100 persons $>$ \\
\hline & $300 \sim 500$ persons & 12.74 & $100-300$ persons $>300-500$ persons \\
\hline & $100 \sim 300$ persons & 22.57 & \\
\hline & Below 100 persons & 27.48 & \\
\hline & Other & 3.28 & \\
\hline Work region & Seoul & 23.20 & Seoul = Gyeonggi > Gyeongsang > \\
\hline & Gyeonggi & 23.02 & Jeolla $>$ Chungcheong $>$ Gangwon, Jeju \\
\hline & Chungcheong & 10.37 & \\
\hline & Gyeongsang & 22.02 & \\
\hline & Jeolla & 14.38 & \\
\hline & Gangwon, Jeju & 4.82 & \\
\hline & Other & 2.18 & \\
\hline
\end{tabular}


with the need for licensing and industrial field experience, respectively. The medical technologists also demonstrated high distributions of $78 \%$ and $70 \%$, respectively (Table 2).

\section{2) Curriculum reform}

Seventy-two percent of the professors and $76 \%$, of the medical technologists thought the curriculum should be integrated into a four-year program (Figure 1A). Thirtyseven percent of the professors and $23 \%$ of the medical technologists responded that an education accreditation institute should precede the integration. Thirty-five percent and $47 \%$ thought that quality management of education should precede the integration, followed by $22 \%$ and $23 \%$ who thought integration should be implemented through administrative and financial support from the government (Figure 1B). Concerning reforming the department of medical technology to accord with changes in the external environment, $28 \%$ of the professors selected strengthening the specialty through integration into a four-year system, and $25 \%$ opted for enhancing educational quality through the establishment of an education accreditation institute. Thirty-five percent of the medical technologists chose curriculum reform to promote job seeking at non-medical institutions, and 27\% chose a reduction of the admission quota for medical technology studies across the country (Figure 1C). Both the professor and medical technologist groups yielded a high rate of comments on this issue, accounting respectively for $49 \%$ and $58 \%$ (Table 3).

\section{3) Practical training courses of college}

Seventy-seven percent of both professors and medical technologists responded that standardizing practical items for each subject was necessary, and 50\% and 82\%, respectively, positively supported practical courses with experts from university hospitals as professors (Table 2).

\section{4) Practical training of hospitals}

The professors and the medical technologists responded negatively concerning the general propriety of clinical practice, by $49 \%$ and $76 \%$, respectively. However, $41 \%$ of

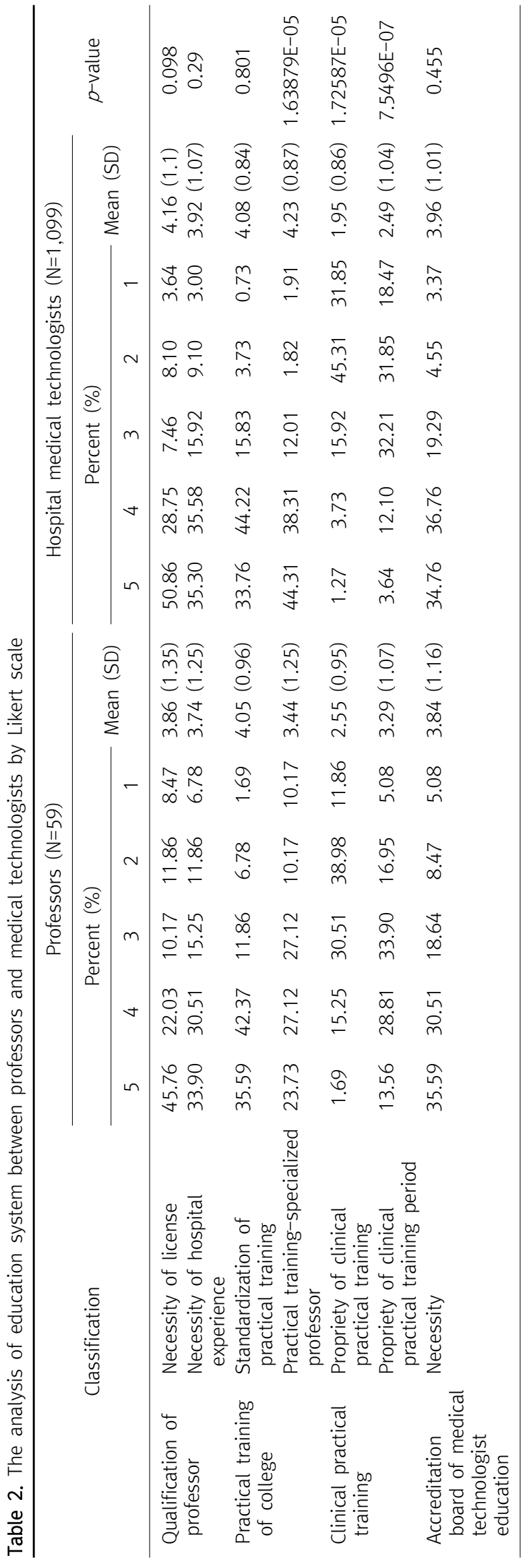


A

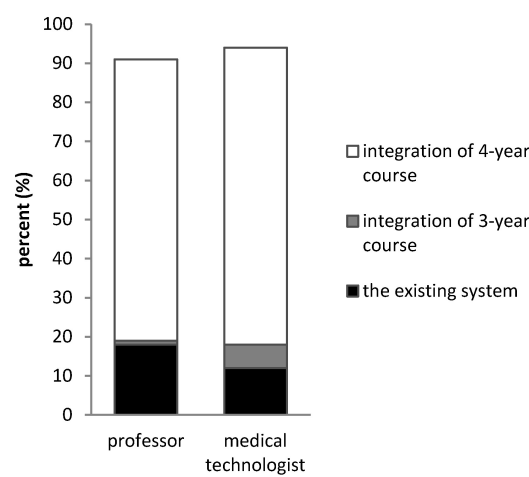

D

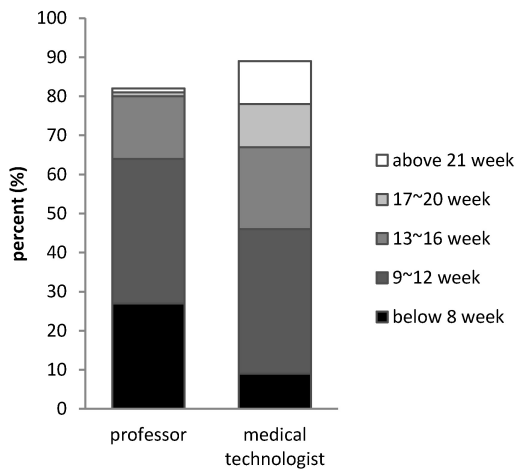

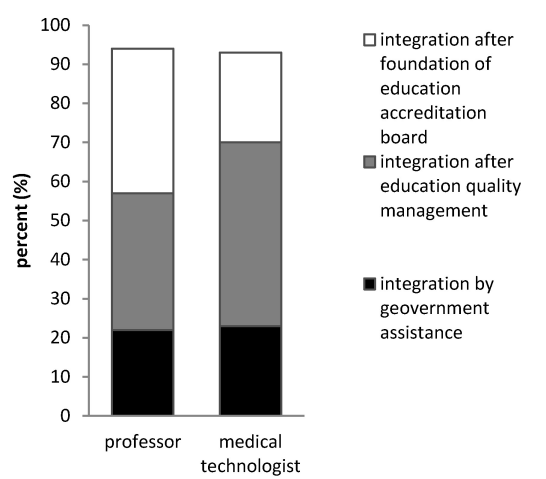

E

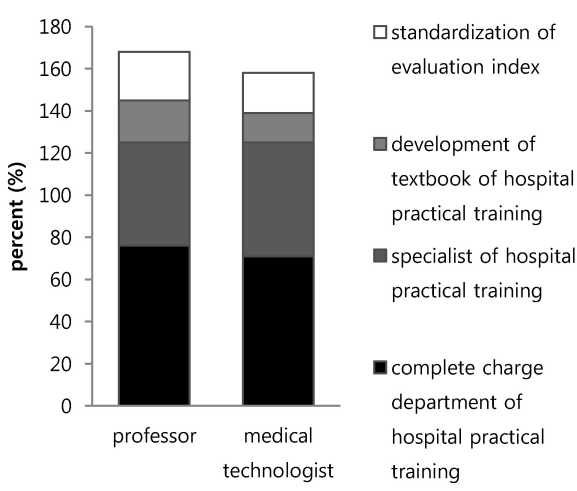

C

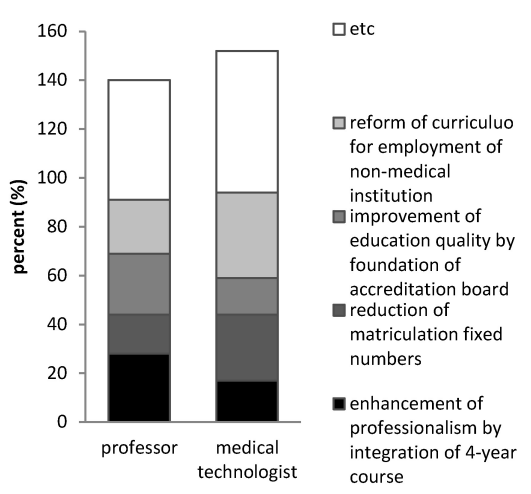

$\mathbf{F}$

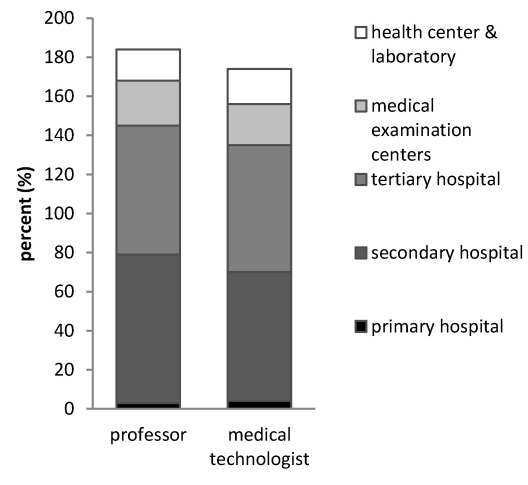

Figure 1. Analysis of the survey responses on the education system between professors and medical technologists. (A) Integration of a dual educational system, (B) Prerequisites for the integration into a four-year system, (C) Direction for medical technology education following changes in the external environment (multiple choice), (D) Desirable duration of a hospital practical training period, (E) Items required to standardize hospital practical training (multiple choice), (F) Suitable size of institutions for hospital practical training (multiple choice).

Table 3. Other comments on Figure $1 \mathrm{C}$

\begin{tabular}{|c|c|}
\hline Order & Other comments \\
\hline 1 & Education should train students for working at hospitals as professionals (including more practical subjects in curriculum) \\
\hline 2 & Specialties and the level of national examination should be reinforced after the integration into the 4-year system. \\
\hline 3 & The system should be improved to allow students to apply for health educator positions as well as nurse. \\
\hline 4 & $\begin{array}{c}\text { Students should be provided with opportunities for job exploration and education in accordance with the changing external } \\
\text { environment (jobs should be ramified into diverse job fields). }\end{array}$ \\
\hline 5 & Education for fostering researchers \\
\hline 6 & It is necessary to make more efforts to strengthen adaptation skills for real tasks. \\
\hline 7 & $\begin{array}{c}\text { The quotas of university departments of medical technology should be reduced. The pass rate of the national examination } \\
\text { should be downsized. }\end{array}$ \\
\hline 8 & The number of employed medical technologists according to number of beds should be legally defined. \\
\hline 9 & the curriculum should be reformed and the association should make more efforts to help graduates successfully get a job. \\
\hline 10 & Full-time medical technologists should be available at medical institutions even though testings are outsourced through CROs. \\
\hline 11 & The quality of education and the level of national examination should be increased. \\
\hline 12 & Disqualification per subject should be revived in the national examination. \\
\hline 13 & The value of medical technologist should be elevated. \\
\hline 14 & More lectures should be given by professors with rich experience in major courses and clinical practice. \\
\hline 15 & The gap should be bridged between real medical fields and educational institutions. \\
\hline 16 & It is necessary to reform the curriculum to be based on practical tasks. \\
\hline
\end{tabular}


the professors gave a positive response to the duration of clinical practice, compared to a negative response by $50 \%$ of the medical technologists (Table 2). The professor and medical technologist groups chose 8 to 12 weeks as the most appropriate period for clinical practice by $37 \%$ rates each, the highest responses (Figure 1D). Concerning requirements for standardizing clinical practice, $76 \%$ of the professors and $71 \%$ of the medical technologists chose the establishment of a department responsible for clinical practice. The two groups chose the employment of clinical practice experts by $49 \%$, and $54 \%$, respectively (Figure 1E). As for the appropriate size of hospitals for clinical practice, the scale of secondary hospitals garnered the highest responses from both the professors and the medical technologists, $76 \%$ and $66 \%$. Tertiary-level size received responses of $66 \%$ and $65 \%$ respectively (Figure 1F).

\section{5) Establishment of Korean Accreditation of Board of Medical Technology Education}

The professors and medical technologists supported the establishment of an institute by $66 \%$ and $71 \%$, respectively (Table 2).

\section{National licensing examination system}

Forty percent of the professors responded positively to the question of whether national examinations (theoretical examination) are suitable for requiring competent medical technologists from clinical fields, while $32 \%$ of the medical technologists responded negatively. Concerning the propriety of the current national examination (practical examination), both the professor and medical technologist groups gave negative responses of $44 \%$ and $64 \%$ respectively. As to whether the computer-based "Smart Device Based Test (SBT)" is better at evaluating the quality of students' capacity in comparison with the current paper-based test, the professors gave a 35\% positive response, 37\% negative responses, and the medical technologists gave a $44 \%$ positive response. Concerning changes in the current method of practical examination, in which pictures are offered, the professors and medical

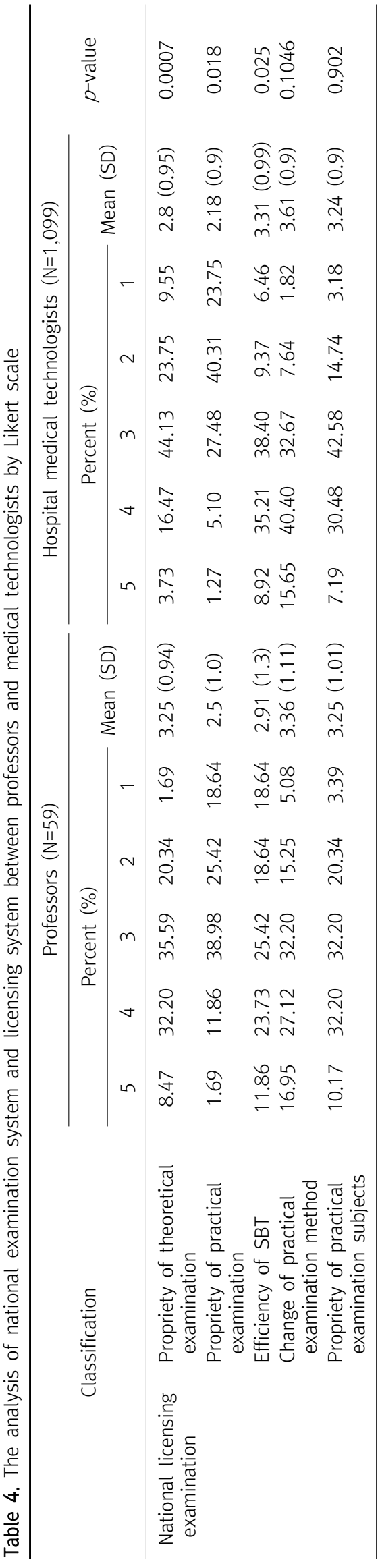


A

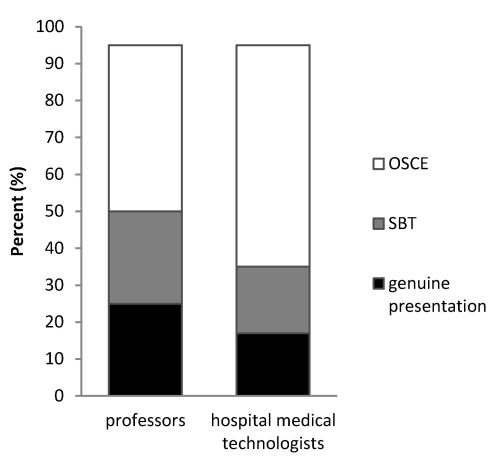

C

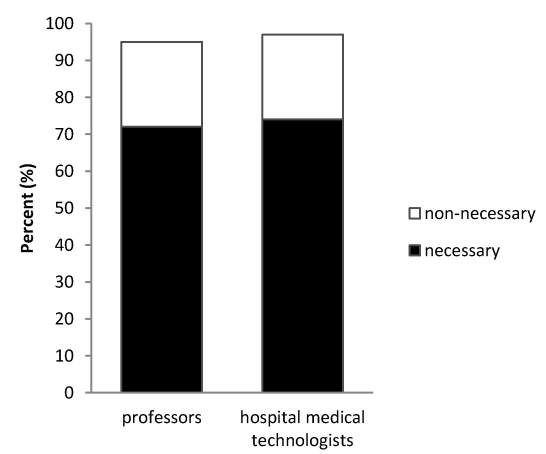

B

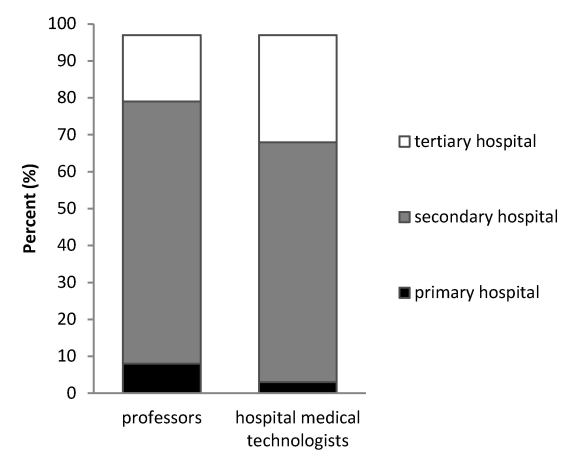

D

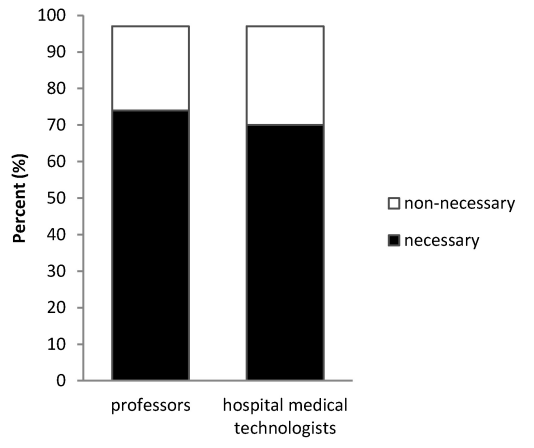

Figure 2. Analysis of the survey responses on a national licensing examination system between professors and medical technologists. (A) Method of practical examination, (B) Suitable size of hospitals for practical examination, (C) Necessity for improving the current licensing system, (D) Necessity for a separate certification system for each of the sub majors other than the current licensing system. technologists gave positive responses of $45 \%$ and $56 \%$, respectively (Table 4). For the method to which the practical examination should be changed, the professors and medical technologists chose the OSCE method by $45 \%$ and $60 \%$, respectively (Figure $2 \mathrm{~A}$ ); the two groups gave positive responses of $42 \%$ and $37 \%$, respectively, concerning the suitability of the subjects currently comprising the practical examination (Table 4). As for the hospital scale, one of the criteria for questions on the current practical examination, both the professors and the medical technologists rated secondary hospitals highly, by $71 \%$ and $65 \%$, respectively (Figure 2B).

\section{National licensing system}

Majorities of professors and medical technologists responded that reforming the licensing system currently in effect was necessary, by rates of $71 \%$ and $74 \%$, respectively (Figure 2C). The professors and medical technologists responded that a separate certification system for each of sub majors other than the licensing system was necessary, by $74 \%$ and $70 \%$, respectively (Figure 2D).

\section{DISCUSSION}

In terms of general characteristics of survey respondents, the region, age, and occupational title of respondents showed an even distribution, which proved the reliability of survey results. In medical technologists, bachelor's degree holders outnumbered college diploma holders. This is probably thought to be the results of increase in 4-year university programs and diversification of education system.

As for the qualification required of professors to produce competent medical technologists, both professors and medical technologists considered that medical technologist license and clinical experience were important to educate medical technologists required at real clinical sites. As for the current dual education system, both professors and medical technologists thought that it was necessary to integrate into 4-year system. The responses showed that education quality management came first as a prerequisite for the integration into 4-year system. Precedent studies also showed that unification of education system by establishing a single 4-year system, and ensuing education 
quality reinforcement would help foster medical technologists capable of performing various tasks of the fast-paced medical technology field [5-7].

The professor and medical technologist groups offered varying opinions about the direction of medical technology education depending on the changes in the external environment. The professors mainly prioritized the integration into the four-year system, whereas the medical technologists favored curriculum reform to promote and support job seeking at non-clinical institutions. The professors were positive about the four-year integration as it would strengthen quality education and, in turn, lead to a downsizing of university admission quotas, producing competent medical technologists. However, the medical technologists working at hospital forefronts reflected pessimism due to the saturation of their workplaces, which would probably have led them to suggest job seeking in other fields after graduating with a medical technology degree.

Quite a big gap appeared in the practical education among universities. Regarding this issue, both the professors and medical technologists perceived a necessity for standardizing practical training at educational institutions. Therefore, the Korea Association of Medical Technologists (KAMT) and the Korean Association of Biomedical Laboratory Science Professors (KABLSP) should cooperate to devise a system that will help implement more standardized practical education in a more systematic manner concerning obligatory practical training of university [8].

Concerning current hospital practical training, professors and medical technologists alike responded in large numbers that it was not suitable; particularly the latter gave negative responses. This result implies that there are many problems with the management of clinical practice from the perspective of hospital workers. Standardized clinical practice is suggested to improve current clinical practice. As to the question of what items are required to achieve this improvement, the professors and medical technologists both responded that it was necessary to establish a department responsible for clinical practice at hospitals and to foster clinical practice experts. The KHPLEI reported that the study of improvement of practical examination of medical technologist [9,10]. The results of our study suggest that the KAMT and KABLSP should reach an agreement concerning the practical management quality of clinical practice. It is recommended that hospitals and universities should conduct further in-depth discussion of more effective clinical practical education.

Considering establishing a system for fostering competent medical technologists, many respondents agreed that it was necessary to found Korean Accreditation of Board of Medical Technology Education [11]. The foundation of this institution should be moved forward with more vigor to accelerate the fostering of talented medical technologists with practical skills. In the clinical field, the process of standardization has continuously developing through CAP and ISO certification [12]. In this context, the KABLSP is currently conducting advanced research.

The national examination is in transition from examining the simple memorization capacity to evaluating problem-solving skills through interpreting problems based on knowledge required in real clinical fields. In terms of theoretical examination, questions are allotted more for interpretation or problem solving rather than memorization. Therefore, a continued increase in the proportion of interpretation-based or problem-solving types of questions is recommended. In terms of practical examinations, both the professors and the medical practitioners responded that it was not suitable, and particularly the latter group gave negative responses. Therefore, breaking away from the current indirect practical examination, and introducing OSCE or SBT (multimedia) questions for a more comprehensive examination is recommended. A more complex examination system is required to assess skills and attitude as well as knowledge of applicants. Both the professors and the medical technologists responded that practical examination subjects are suitable. An additional recommendation is further expansion of the area of clinical 
physiology, which has recently come to be more diversified and specialized [13,14]. Moreover, it is necessary to establish a pool of test questions for the theoretical and practical examination of the subject of molecular biology.

Regarding the current domestic medical technologist licensing system, the professors and medical technologists agreed that it needs to be improved. In consideration of the job scope of the medical technologist, which requires more specialization and sophistication, the quality of university education, a system of national examination, and a national licensing system should be considered, together with consistency in association with one another to advance this specialization [15-17]. Thus, a review of the licensing system will have to take issues concerning these factors into consideration, including posterior examination through license renewal, regular evaluation of disqualification and job aptitude, and obligatory retraining to maintain competence. Both groups regarded a separate certification system for each sub major other than the existing licensing system as necessary; therefore, institutional efforts should be made to address this issue. As a measure to secure specialization in sub majors, existing education for specialists can be promoted. The education of sub majors will have to be converted into regular courses at formally accredited education institutions to produce specialists. Lastly, the future organization of certification and evaluation of medical technology education will perform more vigorously with the management of a higher-level certification exam and the accreditation of education for medical technology specialists approved in the medical community. On conclusion, these result show that the improvement of the quality of university education and hospital practical training should be essential, and the reform of existing national licensing examination should be necessary for fostering competent medical technologist.

\section{요 약}

본 연구는 대학 교육제도와 국가면허시험 제도에 대한 교수
와 병원실무자들의 의견을 조사하여 분석함으로써 우수한 임상 병리사 양성을 위한 정책방향을 결정하는데 목표로 하고 있다. 2016년 8월에 온라인 설문지가 255명의 대학교수들과 4,000 명의 병원실무자들에게 배포되었다. 회수율은 교수들은 59명 (23\%), 병원실무자들은 1,099 명 $(27.7 \%)$ 이 응답하였다. 결과는 기술통계분석과 비교분석을 통해 처리하였다. 대학 교육제도 에서는 교수들과 병원실무자들 모두 대학 및 임상실습 교육의 질적 향상과 교육의 표준화가 필요하다고 조사되었다. 국가면 허시험제도에서는 교수들과 병원실무자들 모두 특히 실기시험 의 개편이 필요하다고 조사되었고, 면허시험제도도 개선이 필 요하다고 조사되었다. 위의 결과들은 교수들과 병원실무자들 은 우수한 임상병리사 양성을 위해서는 대학 및 임상교육의 질 적 향상과 국가면허시험제도의 개선이 필요하다고 생각하고 있 음을 보여준다.

Acknowledgements: This work is supported by the Korea Health Personnel Licensing Examination Institute (Fundref ID: 10.13039/501100003647) research fund (2016).

Funding: None

Conflict of interest: None

\section{REFERENCES}

1. Hwang GY, Cho YK. Investigation of the clinical pathology department student satisfaction and their recognition of employment in Gwangju-Jeonnam province. Korean J Clin Lab Sci. 2010;42(1):55-61.

2. Kim JH, Park JY, Yang BS. A study on the curricular satisfactions and curriculum improvement of the students majoring in clinical pathology. Korean J Clin Lab Sci. 2012;44(4):239-244.

3. Shim MJ. A study on clinical practice of clinical laboratory science students. Korean J Clin Lab Sci. 2004;36(2):233-238.

4. Shim MJ. Factors affecting the job performance of clinical laboratory scientists. Korean J Clin Lab Sci. 2009;41(3):140-144.

5. Hewett R. The future of medical laboratory science- a personal perspective of Dr Who. NZ J Med Lab Science. 2008;62(3): 56-59.

6. Scanlan PM. A review of Bachelor's degree medical laboratory scientist education and entry level practice in the United States. EJIFCC. 2013;24(1): 5-13.

7. Taylor S, Bennett K, Deignan JL, Hendrix EC, Orton SM, Verma S, Schulzbank TE. Molecular pathology curriculum for medical laboratory scientist. J Mol Diagn. 2014; 16(3):288-296.

8. Rye JK, Chang CS. The Perception of Biomedical Laboratory Students on the Clinical Training. Korean J Clin Lab Sci. 2010;42(2):103-109.

9. Ahn YH, Choi SG, Ham CG, Shim MJ, Lee JH, Jekal SJ, et al. The study of improvement and action plan of practical examination 
of Medical Technologist [Internet] Seoul: Korea Health Personnel Licensing Examination Institute; 2011 [cited 2011 November 21] Available from: https://rnd.kuksiwon.or.kr/ last/lastList.do?MENU_ID $=\mathrm{C}-01-01 \&$ reportno $=\&$ s Year $=$ 2011\&SJssfc_code=08\&sResearchindexcd $=$ \&researcherid $=$ \&sRschtasknm $=\&$ PAGE_NUM=1\&PER_PAGE $=$ 10\&IS_PAGE_NEW_SEARCH=Y\&TOTAL_PAGE=152\#none

10. JeKal SJ, Choi CW, Yook GD, Joo SI, Kim YS, Cha GH, et al. The study of long-term improvement plan of practical examination of Medical Technologist [Internet] Seoul: Korea Health Personnel Licensing Examination Institute; 2016 [cited 2016 January 29] Available from: https://rnd.kuksiwon.or.kr/last/ lastList.do?MENU_ID $=C-01-01$ \&reportno $=\&$ sYear $=2016 \&$ sJssfc_code $=08 \&$ sResearchindexcd $=\&$ researcher $\mathrm{id}=\&$ sRsrchtasknm $=\&$ PAGE_NUM=1\&PER_PAGE $=10 \& I S \_$ PAGE_NEW_SEARCH=Y\&TOTAL_PAGE=0\#none

11. Cho KJ, Lee CK, Lee SG, Chung SW, Kim TU, Moon HJ, et al. A Study on certifying systems for clinical laboratory scientists. J Educ Eval Health Prof. 2004;1(1);51-65.

12. Yang MG, Lee WH, Jun JH. Adoption and efficacy of ISO 15189 in medical laboratories for diagnostic and research. Korean J
Clin Lab Sci. 2016;48(2):158-167.

13. Song WH, Ahn YH, Ryu KH, Lee JH, Chang KS, Jekal SJ, et al. The study of the second Job analysis of Medical Technologist. [Internet] Seoul: Korea Health Personnel Licensing Examination Institute; 2012 [cited 2012 October 30] Available from: https://rnd.kuksiwon.or.kr/last/lastList.do?MENU_ID=C-01-01 $\&$ reportno $=\&$ sYear $=2012 \&$ sJssfc_code $=08 \&$ sResearch indexcd $=$ \&researcherid $=\&$ sRsrchtasknm $=\&$ PAGE_NUM=

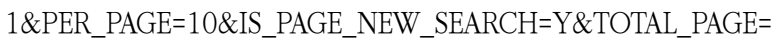
1 \#none

14. Jung SH. A study on educational requirement of forensic medicine for biomedical laboratory science. Korean J Clin Lab Sci. 2015;47(3):153-158.

15. Hosoqaya S. Role of Medical Technologists' training in the future. Jpn J Clin Pathol. 2015;63(1):137-140.

16. Kobayashi N, Kamada Y, Tomiya Y, Kikuchi Y, Omokawa A, Saga T, et al. Viewpoint: skill certifications for Japanese medical technologists. Jpn J Clin Pathol. 2016;64(1):89-95.

17. Risk $\mathrm{N}$. The impact of item parameter drift in computer adaptive testing (CAT). J Appl Meas. 2016;17(1):54-78 